\title{
EVALUASI BELAJAR PESERTA DIDIK (SISWA)
}

\author{
MAHIRAH B. \\ Fakultas Tarbiyah dan Keguruan, UIN Alauddin Makassar \\ Jl. HM. Yasin Limpo No. 36 Makassar \\ Email: mahirahbeddu@gmail.com
}

\begin{abstract}
:
Education is the most important investment for every nation especially for the developing nation, which actively builds its country. Development can only be done by human beings prepared through education, in order to reach the most perfect man as the caliph above earth. The development of education or teaching is inseparable and the responsibility of an educator, how the educator is transforming the knowledge possessed by the existing teaching materials, and by paying attention to the method of teaching that is easily accepted by the learners so that the goal is achieved in accordance with what is expected. Objectives to be achieved then the educator must malakukan an activity called the evaluation of education. Evaluation is part and process of learning which in whole can not be separated from teaching activity, conducting evaluation which is done in education activity has a very main meaning, because evaluation is a measuring tool or process to know level of achievement that have been achieved by student of material or material has been submitted, so that with the evaluation of the objectives of the learning will be seen accurately and convincingly. Evaluation as part of a learning program needs to be optimized, as it not only relies on assessments of learning outcomes, but also needs assessment of inputs, processes, and outputs. One of the important factors for the effectiveness of learning is the evaluation factor both on the learning process and on the learning outcomes. Evaluation is a systematic collection activity of the learning process to determine whether changes occur to students and to what extent these changes affect the life of the students.
\end{abstract}

Keywords: Evaluation Improving Learning Quality \& Improving Education Quality.

\section{PENDAHULUAN}

valuasi dapat mendorong siswa untuk lebih giat belajar secara terus menerus dan juga mendorong guru untuk lebih meningkatkan kualitas proses pembelajaran serta mendorong sekolah untuk lebih meningkatkan fasilitas dan kualitas belajar siswa. Sehubungan dengan hal tersebut, optimalisasi sistem evaluasi memiliki dua makna, pertama adalah sistem evaluasi yang memberikan informasi yang optimal. Kedua adalah manfaat yang dicapai dari evaluasi. Manfaat yang utama dari evaluasi adalah meningkatkan kulitas pembelajaran dan selanjutnya akan terjadi peningkatan kualitas pendidikan.

Hal tersebut menunjukkan bahwa keberhasilan program pembelajaran selalu dilihat dari aspek hasil belajar yang dicapai. Di sisi lain evaluasi pada program pembelajaran membutuhkan data tentang pelaksanaan pembelajaran dan tingkat 
ketercapaian tujuannya. Kondisi yang demikian tidak hanya terjadi pada jenjang pendidikan tinggi, tetapi juga terjadi di jenjang pendidikan dasar dan menengah. Keberhasilan program pembelajaran selalu dilihat dari aspek hasil belajar, sementara implementasi program pembelajaran di kelas atau kualitas proses pembelajaran itu berlangsung jarang tersentuh kegiatan penilaian. Dengan demikian evaluasi sangat dibutuhkan dalam berbagai kegiatan kehidupan manusia sehari-hari, karena disadari atau tidak disadari, sebenarnya evaluasi sudah sering dilakukan, baik untuk diri sendiri maupun kegiatan sosial lainnya. Hal ini dapat dilihat mulai dari berpakaian, setelah berpakaian ia berdiri dihadapan cermin apakah penampilannya sudah wajar atau belum, sampai pada hal-hal yang lebih besar dalam kehidupan manusia. Contohnya ketika seorang pejabat negara berakhir masa jabatannya, maka orang lain yang ada di sekitarnya akan melakukan penilaian atau evaluasi terhadap kinerjanya selama masa kepemimpinannya. Apakah kepemimpinannya tersebut berhasil atau tidak. Begitu pula dalam dunia pendidikan tidak dapat dipisahkan dengan kegiatan evaluasi itu sendiri. Dikatakan demikian, karena evaluasi merupakan salah satu komponen dasar dari sistem pendidikan yang harus dilakukan secara sistematis dan terencana sebagai alat untuk mengukur keberhasilan atau target yang akan dicapai dalam proses pembelajaran.

\section{PENGERTIAN EVALUASI}

Secara etimologi "evaluasi" berasal dan bahasa Inggris yaitu evaluation dari akar kata value yang berarti nilai atau harga. Nilai dalam bahasa Arab disebut alqiamah atau al-taqdir' yang bermakna penilaian (evaluasi). Sedangkan secara harpiah, evaluasi pendidikan dalam bahasa Arab sering disebut dengan al-taqdir altarbiyah yang diartikan sebagai penilaian dalam bidang pendidikan atau penilaian mengenai hal yang berkaitan dengan kegiatan pendidikan. Secara terminologi, beberapa ahli memberikan pendapat tentang pengertian evaluasi diantaranya: Edwind dalam Ramayulis mengatakan bahwa evaluasi mengandung pengertian suatu tindakan atau proses dalam menentukan nilai sesuatu (Ramayulis, 2002). M. Chabib Thoha, mendefinisikan evaluasi merupakan kegiatan yang terencana untuk rnengetahui keadaan objek dengan menggunakan instrumen dan hasilnya dibandingkan dengan tolak ukur untuk memperoleh kesimpulan (Thoha, 1990).

Pengertian evaluasi secara umum dapat diartikan sebagai proses sistematis untuk menentukan nilai sesuatu (ketentuan, kegiatan, keputusan, unjuk-kerja, proses, orang, objek dan yang lainnya) berdasarkan kriteria tertentu melalui penilaian. Untuk menentukan nilai sesuatu dengan cara membandingkan dengan kriteria, evaluator dapat langsung membandingkan dengan kriteria umum, dapat pula melakukan pengukuran terhadap sesuatu yang dievaluasi kemudian membandingkan dengan kriteria tertentu. Dalam pengertian lain antara evaluasi, pengukuran, dan penilaian merupakan kegiatan yang bersifat hirarki. Artinya ketiga 
kegiatan tersebut dalam kaitannya dengan proses pembelajaran tidak dapat dipisahkan satu sama lain dan dalam pelaksanaannya harus dilaksanakan secara berurutan. Dalam kaitan ini ada dua istilah yang hamper sama tetapi sesungguhnya berbeda, yaitu penilaian dan pengukuran. Pengertian pengukuran terarah kepada tindakan atau proses untuk menentukan kuantitas sesuatu, karena itu biasanya diperlukan alat bantu. Sedangkan penilaian atau evaluasi terarah pada penentuan kualitas atau nilai sesuatu. Evaluasi belajar dan pembelajaran adalah proses untuk menentukan nilai belajar dan pembelajaran yang dilaksanakan, dengan melalui kegiatan penilaian atau pengukuran belajar dan pembelajaran. Sedangkan pengertian pengukuran dalam kegiatan pembelajaran adalah proses membandingkan tingkat keberhasilan belajar dan pernbelajaran dengan ukuran keberhasilan belajar dan pembelajaran yang telah ditentukan secara kuantitatif sementar pengertian penilaian belajar dan pembelajaran adalah proses pembuatan keputusan nilai keberhasilan belajar dan pembelajaran secara kualitatif.

Dengan adanya evaluasi, peserta didik dapat mengetahui sejauh mana keberhasilan yang telah dicapai selarna mengikuti pendidikan. Pada kondisi dimana siswa mendapatkan nilai yang mernuaskan, maka akan memberikan dampak berupasuatu stimulus, motivator agar siswa dapat lebih meningkatkan prestasi. Pada kondisi dimana hasil yang dicapai tidak memuaskan, maka siswa akan berusaha memperbaiki kegiatan belajar, namun demikian sangat diperlukan pemberian stimulus positif dari guru/pengajar agar siswa tidak putus asa. Sedangkan evaluasi dalam pendidikan Islam adalah pengambilan sejumlah yang berkaitan dengan pendidikan Islam guna melihat sejauh mana keberhasilan pendidikan yang selaras dengan nilai-nilai Islam sebagai tujuan dari pendidikan itu sendiri. Lebih jauh Jalaludin mengatakan bahwa evaluasi dalam pendidikan Islam telah menggariskan tolak ukur yang serasi dengan tujuan pendidikannya. Baik tujuan jangka pendek yaitu membimbing manusia agar hidup selamat di dunia, maupun tujuan jangka panjang untuk kesejahteraan di akhirat nanti. Kedua tujuan tersebut menyatu dalam sikap dan tingkah laku yang mencerminkan akhlak yang mulia. Sebagai tolak ukur dan akhlak mulia ini dapat dilihat dari cerminan tingkah laku dalam kehidupan sehari-hari.

Al-Qur'an sebagai dasar segala disiplin ilmu termasuk ilmu pendidikan Islam secara implisit sebenamya telah memberikan deskripsi tentang evaluasi pendidikan dalam Islam. Hal ini dapat ditemukan dari berbagai system evaluasi yang ditetapkan Allah di antaranya:

1. Evaluasi untuk mengoreksi balasan amal perbuatan manusia, sebagai mana yang tersirat dalam QS. Al-Zalzalah: 7 - 8.

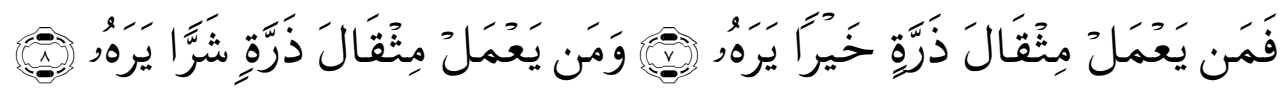


Terjemahan:

Barang siapa yang mengerjakan kebaikan seberat dzarrah pun, niscaya dia akan melihat (balasan)-nya. Dan barang siapa yang mengerjakan kejahatan sebesar dzarrahpun, niscaya dia akan melihat (balasan)-nya pula.

2. Nabi Sulaiman as. pernah mengevaluasi kejujuran seekor burung hud-hud yang memberitahukan adanya kerajaan yang diperintah oleh seorang wanita cantik, yang dikisahkan dalam QS. Al-Naml: 27

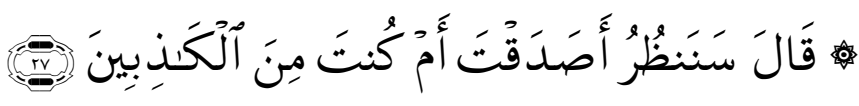

Terjemahnya:

Berkata Sulaiman: "Akan kami lihat, apa kamu benar, ataukah kamu termasuk orang-orang yang berdusta.

3. Sebagai contoh ujian (tes) yang berat kepada Nabi Ibrahim as., Allah memerintahkan beliau untuk menyembelih anaknya Ismail yang amat dicintai. Tujuannya untuk kadar untuk mengetahui kadar keimanan dan ketaqwaan serta ketaatannya kepada Allah, seperti disebutkan dalam Q.S, AlShaffat: 103-104.

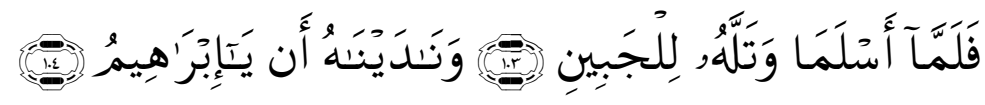

Terjemahnya:

Tatkala keduanya Telah berserah diri dan Ibrahim membaringkan anaknya atas pelipis (nya), (nyatalah kesabaran keduanya). Dan kami panggillah dia: "Hai Ibrahim, Sesungguhnya kamu telah membenarkan mimpi itu, Sesungguhnya demikianlah kami memberi batasan, kepada orang-orang yang berbuat baik, sesungguhnya ini benar-benar suatu ujian yang nyata. Dan kami tebus anak itu dengan seekor sembelihan yang besar.

Dari beberapa pengertian tersebut di atas baik dari makna bahasa istilah maupun dari ayat al-Qur'an, maka dapat diambil kesimpulan bahwa evaluasi merupakan suatu proses tolak ukur untuk mengetahui sejauh mana tingkat keberhasilan yang dicapai dalam dunia pendidikan. Oleh karena itu evaluasi merupakan hal yang signifikan dilakukan dalam dunia pendidikan, karena mempunyai manfaat yang amat berpengaruh, begitu juga dengan bidang-bidang yang lain termasuk dalam kebidupan, yang paling utama adalah evaluasi terhadap diri sendiri. 


\section{TUJUAN, FUNGSI, DAN MANFAAT EVALUASI \\ Tujuan Evaluasi}

Evaluasi adalah suatu kegiatan yang disengaja dan bertujuan. Kegiatan evaluasi dilakukan dengan sadar oleh guru dengan tujuan untuk memperoleh kepastian mengenai keberhasilan belajar siswa dan memberikan masukan kepada guru mengenai apa yang dia lakukan dalam kegiatan pengajaran. Dengan kata lain, evaluasi yang dilakukan oleh guru bertujuan untuk mengetahui bahan bahan pelajaran yang disampaikan apakah sudah dikuasi oleh siswa ataukah belum. Selain itu, apakah kegiatan pegajaran yang dilaksanakannya itu sudah sesuai dengan apa yang diharapkan atau belum.

Menurut Sudirman N, dkk, bahwa tujuan penilaian dalam proses pembelajaran adalah:

1. Mengambil keputusan tentang hasil belajar.

2. Memahami siswa,

3. Memperbaiki dan mengembangkan program pengajaran.

Selanjutnya, mengatakan bahwa pengambilan keputusan tentang hasil belajar merupakan suatu keharusan bagi seorang guru agar dapat mengetahui berhasil tidaknya siswa dalam proses pembelajaran. Ketidakberhasilan proses pembelajaran itu disebabkan antara lain sebagai berikut:

1. Kemampuan siswa yang rendah.

2. Kualitas materi pelajaran tidak sesuai dengan tingkat usia anak.

3. Jumlah bahan pelajaran terlalu banyak sehingga tidak sesuai dengan waktu yang diberikan.

4. Komponen proses belajar dan mengajar yang kurang sesuai dengan tujuan yang telah ditetapkan oleh guru itu sendiri.

Di samping itu, pengambilan keputusan juga sangat diperlukan untuk memahami siswa dan mengetahui sampai sejauh mana dapat memberikan bantuan terhadap kekurangan siswa. Evaluasi juga bermaksud meperbaiki dan mengembangkan program pengajaran. Dengan demikian, tujuan evaluasi adalah untuk memperbaiki cara, pembelajaran, mengadakan perbaikan dan pengayaan bagi siswa, serta menempatkan siswa pada situasi pembelajaran yang lebih tepat sesuai dengan tingkat kemampuan yang dimilikinya. Tujuan lainnya adalah untuk memperbaiki dan mendalami dan memperluas pelajaran, dan yang terakhir adalah untuk memberitahukan atau melaporkan kepada para oran gtua/wali siswa mengenai penentuan kenaikan kelas atau penentuan kelulusan siswa.

\section{Fungsi Evaluasi}

Evaluasi yang sudah menjadi pokok dalam proses keberlangsungan, pendidikan maka sebaiknya dikerjakan setiap hari dengan jadwal yang sistematis dan terencana. Guru dapat melakukan evaluasi tersebut dengan menempatkannya secara satu kesatuan yang saling berkaitan dengan mengimplementasikannya 
pada satuan materi pembelajaran. Bagian penting lainnya yaitu bahwa guru perlu melibatkan siswa dalam evaluasi sehingga secara sadar dapat mengenali perkembangan pencapaian hasil belajar pembelajaran mereka, Sehingga salah satu komponen dalam pelaksanaan pendidikan. Evaluasi mempunyai beberapa fungsi. Berdasarkan Undang-undang RI tentang Sisdiknas No. 20 Tahun 2003 Pasal 58 ayat 1 bahwa evaluasi hasil belajar peserta didik dilakukan untuk membantu proses, kemajuan, dan perkembangan hasil belajar peserta didik secara berkesinambungan. Menurut M. Ngalim Purwanto bahwa kewajiban bagi setiap guru untuk melaksanakan kegiatan evaluasi itu (Purwanto, 1991). Hal ini karena pada akhirnya guru harus memberikan informasi lembaganya ataupun kepada siswanya itu sendiri, mengenai bagaimana dan sampai dimana penguasaan dan kemampuan telah dicapai oleh siswa tentang materi dan keterampilan mengenai mata pelajaran yang telah diberikannya.

Dari kedua pendapat tersebut dapat dipahami bahwa evaluasi mutlak dilakukan dan merupakan kewajiban bagi setiap guru dalam setiap saat melaksanakan kegiatan pembelajaran. Disebut demikian, karena menjadi salah satu tugas pokok guru selain mengajar, adalah melaksanakan kegiatan evaluas. Evaluasi dan kegiatan mengajar merupakan satu rangkaian yang sangat erat dimana antara keduanya tidak dapat dipisahkan. Lebih dari itu juga adalah guru harus mengetahui tugas dan fungsi evaluasi itu sendiri. Dikatakan demikian agar guru mudah menerapkannya untuk menilai kegiatan pembelajaran pada rumusan tujuan yang telah ditetapkannya tercapai. Untuk hal tersebut, berikut penulis juga mengemukakan beberapa pendapat para ahli, yaitu:

Jahja Qohar Al-Haj, mengemukakan bahwa fungsi evaluasi dari sisi siswa secara individual, dan dari segi program pengajaran.

a. Dilihat dari segi siswa secara individu, evaluasi berfungsi sebagai: mengetahui tingkat pencapaian siswa dalam suatu proses pembelajaran yaitu:

1) Menetapkan keefektifan pengajaran dan rencana kegiatan.

2) Memberi basis Laporan kemajuan siswa

3) Menetapkan kenaikkan dan kelulusan

b. Dilihat dari segi program pengajaran, evaluasi berfungsi:

1) Memberi dasar pertimbangan kenaikan dan promosi siswa.

2) Memberi dasar penyusunan dan penempatan kelompok siswa yang homogen.

3) Diagnosis dan remedial pekerjaan siswa.

4) Memberi dasar pembimbingan dan penyuluhan.

5) Dasa pemberian angka dan rapor bagi kemajuan belajar siswa.

6) Memberi motivasi belajar bagi siswa.

7) Mengidentifikasi dan mengkaji kelainan siswa.

8) Menafsirkan kegiatan sekolah ke dalam masyarakat

9) Untuk mengadministrasi sekolah. 
10) Untuk mengembangkan kurikulum.

11) Mempersiapkan penelitian pendidikan di sekolah (Al-Haj, 1985).

Dengan demikian dapat dianalisis bahwa tampaknya kegiatan tersebut untuk memberikan masukan bagi siswa dan pihak sekolah dalam hal mengetahui tentang perkembangan belajar dan perkembangan grafik belajar serta kelulusan siswanya. Semua informasi yang masuk pada pihak lembaga (sekolah) tempat siswa belajar tersebut akan menjadi data yang akurat dalam melakukan evaluasi pada pengembangan dan perbaikan sekolah. Lebih-lebih lagi pada bagaimana mengembangkan mutu atau kualitas siswa. Sedangkan Nana Sudjana menjelaskan bahwa, evaluasi berfungsi sebagai berikut:

1. Untuk mengetahui tercapai tidaknya tujuan instruksional khusus. Dengan fungsi ini dapatlah diketahui bahwa tingkat penguasaan bahan pelajaran yang dikuasai oleh siswa. Dengan kata lain, dapat diketahui bahwa hasil belajar siswa tersebut baik atau tidak baik.

2. Untuk mengetahui keaktifan proses pembelajaran yang dilaksanakan guru. Rendahnya capaian hasil belajar yang diperoleh siswa tidak semata-mata disebabkan oleh ketidakmampuan siswa itu sendiri. Tetapi boleh jadi karena guru yang kurang bagus dalam mengajar. Dengan penilaian yang dilakukan akan dapat diketahui apakah hasil belajar itu karena kemampuan siswa atau juga karena factor guru, selain itu dengan penilaian tersebut dapat menilai guru itu sendiri dan hasilnya dapat dijadikan sebagai bahan dalam memperbaiki tindakan mengajar berikutnya.

Sementara itu menurut rumusan fungsi yang dipaparkan oleh pihak Departemen Agama RI, bahwa penilaian adalah sebagai berikut:

1. Memberikan umpan balik kepada guru sebagai dasar untuk mengajarnya, mengadakan perbaikan bagi siswa, serta menempatkan pada situasi belajar mengajar yang lebih tepat sesuai dengan tingkat kemampuan yang dimiliki oleh siswa.

2. Menentukan nilal hasil belajar siswa antara lain diperlukan untuk pemberian laporan pada orang tua sebagai penentuan kenaikan kelas dan penentuan kelulusan siswa.

3. Menjadi bahan untuk menyusun laporan dalam rangka penyem-purnaan program belajar mengajar yang sedang berjalan (Depag RI, 1988/1989).

Selain itu, dikemukakan pula pendapat Wayan Nurkencana, dkk, sebagai berikut, yaitu:

1. Untuk mengetahui taraf kesiapan siswadalam menempatkan suatu pendidikan tertentu.

2. Untuk mengetahui seberapa jauh hasil yang telah dicapai dalam kegiatan proses pendidikan dan pengajaran itu yang dilaksanakan. 
3. Untuk mengetahui apakah suatu matapelajaran yang telah diajarkan dapat dilanjutkan dengan bahan yang baru atau harus diulang kembali.

4. Untuk mendapatkan bahan-bahan informasi dalam memberikan bimbingan tentang jenis pendidikan atau jenis jabatan yang cocok untuk siswatersebut.

5. Untuk mendapatkan bahan-bahan informasi.

6. Yang menentukan apakah sesorang siswa dapat dinaikan ke kelas di atasnya atau tidak ataukah la tetap pada kelas semula.

7. Untuk membandingkan apakah prestasi yang dicapai siswa sudah sesuai dengan kapasitasnya atau belum.

8. Untuk menafsirkan apakah siswa telah dilepaskan ke dalam masyarakat atau ke perguruan tinggi.

9. Untuk mengetahui taraf efisiensi metode yang dipergunakan dalam lapangan pendidikan (Nurkencana, 1983).

Dari keseluruhan pendapat para ahli tersebut di atas, dapat dilihat bahwa redaksinya berbeda antara satu dengan yang lain. Akan tetapi substansinya bermuara pada satu titik tujuan atau sasaran, yaitu bagaimana dengan fungsi evaluasi tersebut menjadi parameter bagi pihak siswa, guru, sekolah, masyarakat, dan orang tua terhadap kegiatan pembelajaran. Bagi siswa dengan evaluasi la akan mengetahui kemampuan perkembangan grafik belajarnya, apakah ada kemajuan atau tidak, ataukah semakin menurun. Apakah la naik kelas atau tidak, ataukah la lulus dalam ujian sekolah atau tidak lulus. Bagi orang tua, mereka akan mudah untuk mengetahui bahwa anaknya memiliki kualitas atau tidak, naik ke kelas berikutnya atau tidak. Ini dapat dilihat dari buku laporan hasil pendidikannya. Begitu juga bagi pihak sekolah. Kepala sekolah serta semua guru-guru akan dapat mengetahui bagaimana perkembangan grafik kelulusan siswanya setiap tahun. Demikian juga dengan siswa-siswanya yang tidak naik ke kelas berikutnya. Masyarakat juga akan mengetahui dengan evaluasi tersebut, apakah sekolah yang ada di sekelilingnya tersebut memiliki mutu atau tidak. Kemudian masyarakat dapat membandingkan antara satu sekolah dengan sekolah lain dalam hal menyekolahkan atau melanjutkan pendidikan putra-putrinya. Apalagi masyarakat bila menjadikan output dan lembaga pendidikan itu untuk menjadi tenaga kerja yang siap pakai, lalu bagaimana dengan produktifitasnya sehubungan dengan latar belakang keilmuan yang dimiliki itu. Jadi masyarakat sebagai pengguna tenaga lulusan dari sekolah itu akan melihat dengan sendirinya dari hasil evaluasi itu sendiri. Selain fungsi-fungsi tersebut di atas, berikut dikemukakan beberapa fungsi evaluasi, antara lain:

\section{Penilaian Berfungsi Selektif}

Dengan cara mengadakan penilaian guru mempunyai cara untuk mengadakan seleksi atau penilaian terhadap siswanya. Penilaian itu sendiri mempunyai berbagai tujuan, antara lain: 
a. Untuk memilih siswa yang dapat diterima di sekolah tertentu.

b. Untuk memilih siswa yang dapat naik ke kelas atau tingkat berikutnya.

c. Untuk memilih siswa yang seharusnya mendapat beasiswa.

d. Untuk memilih siswa yang sudah berhak meninggalkan sekolah, dan sebagainya.

\section{Penilaian Berfungsi Diagnostik}

Apabila alat yang digunakan dalam penilaian cukup memenuhi persyaratan, maka dengan melihat hasilnya, guru akan mengetahui kelemahan siswa. Di samping itu, diketahui pula sebab musabab kelemahan itu. Jadi dengan mengadakan penilaian sebenarnya guru mengadakan diagnosis kepada siswa tentang kebaikan dan kelemahannya. Dengan diketahuinya sebab-sebab kelemahan ini, akan lebih mudah dicari cara untuk mengatasi.

\section{Penilaian Berfungsi Sebagai Penempatan}

Sistem baru yang kini banyak dipopulerkan di negara Barat, adalah sistem belajar sendiri. Belajar sendiri dapat dilakukan dengan cara mempelajari sebuah paket belajar, baik itu berbentuk modul maupun paket belajar yang lain. Sebagai alasan dari timbulnya sistem ini adalah adanya pengakuan yang besar terhadap kemampuan individual. Setiap siswa sejak lahirnya telah membawa bakat sendirisendiri sehingga pelajaran akan lebih efektif apabila disesuaikan dengan pembawaan yang ada. Akan tetapi disebabkan karena keterbatasan sarana dan tenaga, pendidikan yang bersifat individual kadang-kadang sukar sekali dilaksanakan. Pendekatan yang lebih bersifat melayani perbedaan kemampuan, adalah pengajaran secara kelompok. Untuk dapat menentukan dengan pasti di kelompok mana seorang siswa harus ditempatkan, digunakan suatu penilaian. Sekelompok siswa yang mempunyai hasil penilaian yang sama, akan berada dalam kelompok yang sama dalam belajar.

\section{Penilaian Berfungsi Sebagai Pengukur Keberhasilan}

Fungsi keempat dari penilaian ini dimaksudkan untuk mengetahui sejauh mana suatu program berhasil diterapkan. Keberhasilan program ditentukan oleh beberapa faktor yaitu faktor guru, metode mengajar, kurikulum, sarana, dan system administrasi.

\section{Manfaat Evaluasi}

Secara umum manfaat yang dapat diambil dari kegiatan evaluasi dalam pembelajaran, yaitu:

a. Memahami sesuatu: mahasiswa (entry behavior, motivasi, dll), sarana dan prasarana, dan kondisi dosen.

b. Membuat keputusan: kelanjutan program penanganan "masalah", dll.

c. Meningkatkan kualitas PBM: komponen-komponen PBM 
Sementara secara lebih khusus evaluasi akan member manfaat bagi pihak-pihak yang terkait dengan pembelajaran, seperti siswa, guru, dan kepala sekolah.

1. Bagi Siswa; mengetahui tingkat pencapaian tujuan pembelajaran Memuaskan atau tidak memuaskan

2. Bagi Guru; a) mendeteksi siswa yang telah dan belum menguasai tujuan melanjutkan remedial atau pengayaan, b) ketepatan materi yang diberikan jenis, lingkup, tingkat kesulitan, c) Ketepatan metode yang digunakan.

3. Bagi Sekolah; a) Hasil belajar cermin kualitas sekolah, b) membuat program sekolah, c) pemenuhan standar.

Dengan demikian dapatlah difahami bahwa evaluasi sangat perlu/bermanfaat dan merupakan syarat mutlak untuk perbaikan, agar mempunyai makna yang signifikan bagi semua pihak. Jika kita temukan hubungan antara hasil belajar dengan efektivitas metode mengajar terbukalah kemungkinan untuk mengadakan perbaikan. Sebelum kita mengevaluasi kemampuan metode baru pada sejumlah peserta didik, perlu kita pikirkan bahwa proses pembelajaran itu dinamis, senantiasa terjadi perubahan pada guru maupun murid dalam interaksi itu. Di samping hasil belajar seperti diharapkan oleh guru mungkin timbul pula hasil sampingan yang positif maupun negatif misalnya, murid-murid menguasai bahan yang disajikan akan tetapi la disamping itu merasa senang atau benci terhadap tindakan pribadi gurunya.

\section{KESIMPULAN}

Berdasarkan pada uraian pembahasan tersebut di atas maka penulis dapat menarik kesimpulan sebagai berikut:

Evaluasi sebagai suatu kegiatan mengumpulkan data dan informasi mengenai kemampuan belajar siswa, untuk menilai sudah sejauh mana program (pengembangan sistem instruksional) telah berjalan, dan juga sebagai suatu alat untuk menentukan apakah tujuan pendidikan dan proses pembelajaran dalam mengembangkan ilmu pengetahuan telah berlangsung sebagaimana mestinya. Evaluasi bertujuan untuk mengetahui tingkat pencapaian siswa dalam suatu proses pembelajaran, sekaligus untuk memahami siswa sampai sejauh mana dapat memberikan bantuan terhadap kekurangan-kekurangan siswa, dengan tujuan menempatkan siswa pada situasi pembelajaran yang lebih tepat sesuai dengan tingkat kemampuan yang dimilikinya. Sedangkan fungsi evaluasi untuk membantu proses, kemajuan dan perkembangan hasil belajar peserta didik secara berkesinambungan, dan sekaligus dapat mengetahui kemampuan dan kelemahan siswa pada bidang studi tertentu, sekaligus dapat memberikan informasi kepada orang tua wali siswa mengenai penentuan kenaikan kelas atau penentuan kelulusan siswa. 


\section{DAFTAR PUSTAKA}

Abdorrakhman, Gintings. Esensi Praktis Belajar dan Pembelajaran. Buah Batu Bandung, 2008.

Al-Haj, Jahja Qohar. Evaluasi Pendidikan Agama, Cet. I; Jakarta: Ciawi Jaya, 1985.

Departemen Agama RI. Pedoman Sistem Penilaian Madrasah Aliyah. Jakarta Dirjen Bimbaga Islam Proyek Madrasah Aliyah, 1988/1989.

Departemen Pendidikan dan Kebudayaan. Kamus Besar Bahasa Indonesia. Cet.V: Jakarta 1976.

Dimyati dan Mujiono. Belajar dan Pembelajaran. Cet III; Jakarta Cipta, 2006.

Djamarah, Syaiful Bahri. Guru Dan Anak Didik Dalam Interaksi Edukatif Suatu Pendekatan Teoritis Psikologis. Cet. II; Jakarta: PT Rineka Cipta, 2005.

Gronlund, E. N. Improving Marking and Reporting in Classroom Instruction, Mac Millan Publishing, Co, Inc. NewYork, Collier Mac Millan Publishers, London, 1974.

Hergenhanhn, B. R. dan Matthew H. Olson, Theories of Learning (Teori Belajar). Edisi Ketujuh. Cet. 1. Jakarta: Kencana, 2008.

Muijs, Daniel, dan David Reynolds. Effective Teaching, Second Edition, diterjemahkan oleh Helly Prajitno Soetjipto dan Sri Mulyantini Soetjipto dengan judul Teori dan Aplikasi. Edisi Kedua. Cet. I, Yogyakarta: Pustaka Pelajar, 2008.

Nasution. Teknologi Pendidikan, Jakarta: Bumi Aksara, 2008. http://www.bloomet.etAll. Com. Tanggal 22 Mei 2009.

Nurkencana, Wayan dan Sumartana. Evaluasi Pendidikan. Surabaya: Usaha Nasional, 1983.

Purwanto, M. Ngalim. Ilmu Pendidikan Teoritis dan Praktis, Bandung: PT Remaja Rosdakarya, 1991.

Ramayulis. Metodologi Pendidikan Agama Islam, Kalam Mulia: Jakarta 2002.

Sabri, Ahmad. Strategi Belajar Mengajar, Cet. I. Ciputat Press. 2005.

Salim, Peter. The Contemporary English Indonesia Dictionary. Ed II. Jakarta: Modern English Press, 1986.

Sudiono, Anas. Pengantar Evaluasi Pendidikan, PT. Grafindo Persada, Jakarta. 2005.

Sykes, J. B. (ed), The Concise Oxford Dictionary of Corred English, (Oxford: Calredom Press; 1976.

Thoha, M. Chabib. Teknik Evaluasi Pendidikan, PT. Raja Grafindo: Jakarta 1990. 